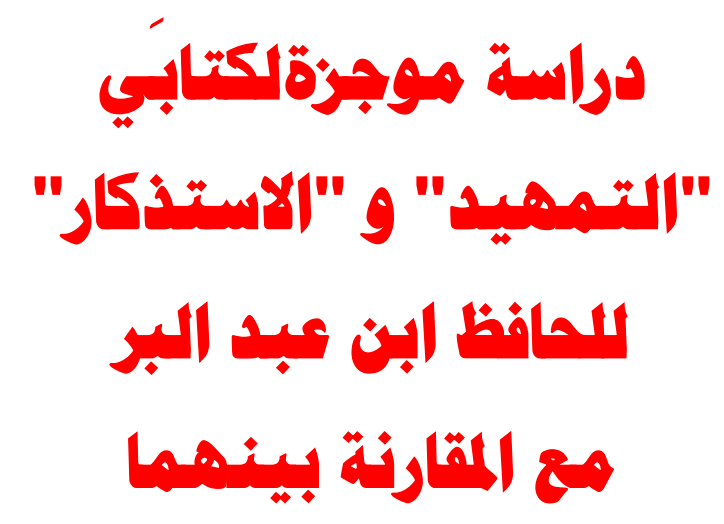

إعداد

د. فر از الحق بن نجم الحق إعق

دكتوراه في علوم الحديث بالجامعة الإسلامية بالمدينة المنورة.

A Study on "Al-Tamheed" and "Al-Istidhkar" by Hafiz Ibn Abd al-Barr with comparison between them By

Dr. FarazUlHaq s/o NajmulHaq

Ph.D in Sciences of Prophet's Tradition, at the Islamic University of Madinah. 
دراسة موجزة لكتابَ"|لتمهيد" و "الاستذكار" للحافظ ابن عبد البر مع المقارنة بينهما 
مجلة كلية الثريعة والقانون بتفهنا الأشر اف ـ دقهلية

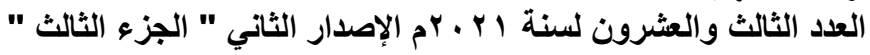

دراسة موجزة لكتّابَي" التمهيد "و "الاستثكار" للحافظ ابن عبد البر

مع المقارنة بينهما

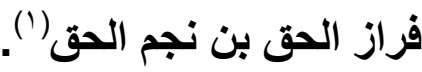

قسم علوم الحديث، كلية الحديث الشريف و الدراسات الإسلامية، الجامعة الإسلامية المدينة المنورة، المملكة العربية السعودية.

\section{البريد الإكتروني:abuhasanfaraz@gmail.com}

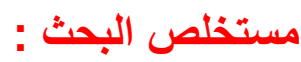

ذكرْتُ في هذا البحث نرجمة موجزة لحافظ المغرب ابن عبد البر المالكي

(ت (ت7 ـــ)، ونشأته،وأشهر شيوخه وتلامذته، ومنزلته بين العلماء وثناؤهم عليه، وما

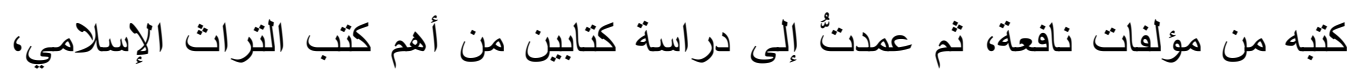
و هما: "التمهيد" و"الاستذكار"، وهما من أشهر شروح "موطأ الإمام ماللك" الذي يعتبر من أصح كتب السنة، فأبرزتُ في هذا البحث سبب تأليف ابن عبد البر هذين الكتابين، وموضوعهما، وترتيبهما، وما لكلّ واحد منهما من ميزة على الآخر، مع التطرق إلى هي ذكر عناية العلماء بهما، ولأن الكتابين متشابهان في موضوعهما، إذ كلاهما شرح

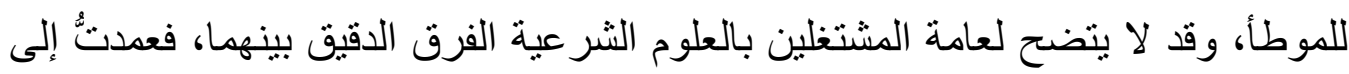
وضع جدولٍٍ للمقارنة بين الكتابين في خمسة عشر عنصرًا يتضح من خلالها ما لكلِ كتاب من هذين الكتابين خاصية، وختمت بحثي بذكر أبرز نتائج البحث، والتوصيات. الكلمات المفتاحية: ابن عبد البر ، التمهيد ، الاستذكار ، الموطأ.

دكتور اه في قسم علوم الحديث، كلية الحديث الثريف والدراسات الإسلامية، الجامعة الإسلامية المدينة المنورة، المملكة العربية السعودية. 
دراسة موجزة لكتابَي"التمهيد" و "الاستذكار" للحافظ ابن عبد البر مع المقارنة بينهما

A Study on "Al-Tamheed" and "Al-Istidhkar" by Hafiz Ibn Abd al-Barr with comparison between them

FarazUlHaq s/oNajmulHaq(').

Department of Sciences of Prophet's Tradition, in the Faculty of Noble Hadith and Islamic Studies at the Islamic University in AlMadinahAIMunawwarah, Kingdom of Saudi Arabia.

E-mail: abuhasanfaraz@gmail.com ABSTRACT:

I mentioned in this research a brief translation of the Hafiz alMaghrib Ibn Abd al-Barr al-Maliki And his upbringing, his teachers and students, his standing among scholars and their praise for him, and what he wrote of useful books, then I set out to study two of the most important books of Islamic heritage: "Al Tamheed" and "Al-Istidhkar", which are two of the most famous commentaries on "Muwatta"by Imam Malik which is considered one of the most authentic books of the Sunnah.So I highlighted the reason behind Ibn Abd al-Barr's authorship of these two books, their topic, their arrangement, and the advantage of each of them over the other. But because the two books are similar in content, and it may not be clear to the general student of Sharia sciences the exact difference between them, so I set out a table for comparison between the two books in thirteen elements through which to clarify the characteristics of each of these two books, and I concluded my research by mentioning the most prominent research results and recommendations.

Keywords: Ibn Abd al-Barr, Al Tamheed, Al-Istidhkar, Muwatta .

(1) Ph.D in Department of Sciences of Prophet's Tradition, in the Faculty of Noble Hadith and Islamic Studies at the Islamic University in AlMadinah AIMunawwarah. 


\section{المقدمة}

الحمد لله رب العالمين، والصلاة والسلام على أشرف الأنبياء و المرسلين نبينا

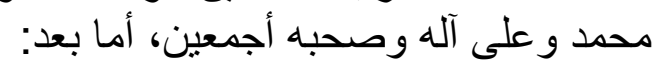

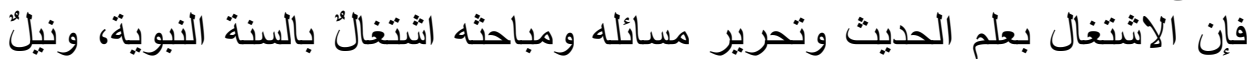

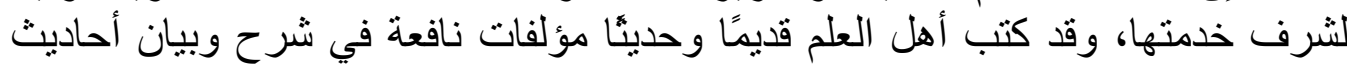

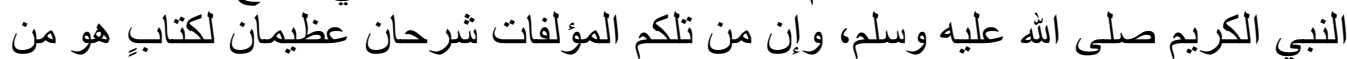

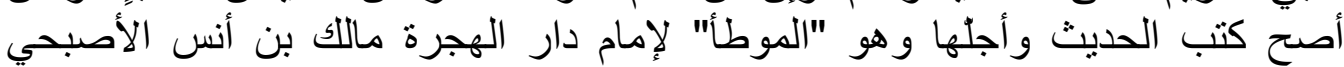

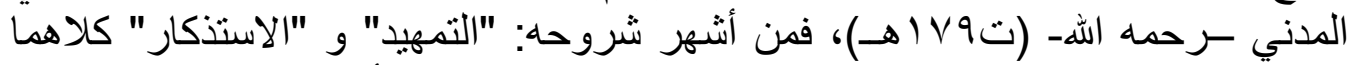

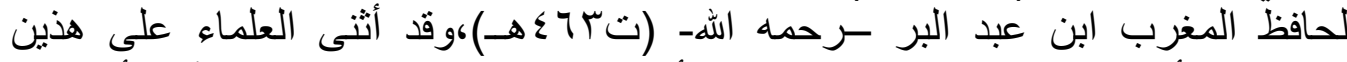

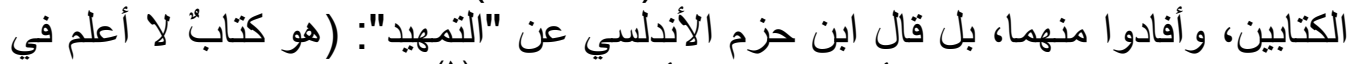

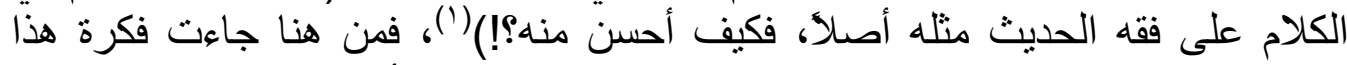

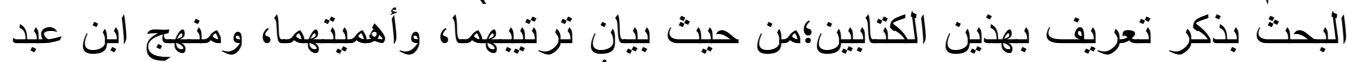

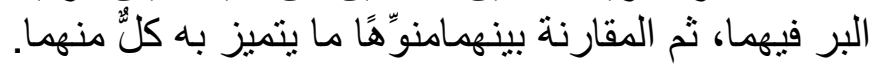

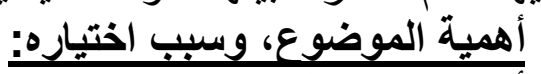

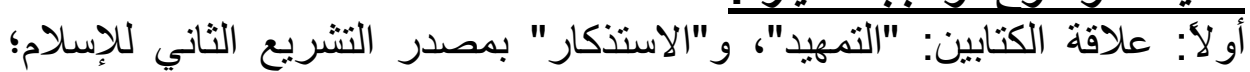

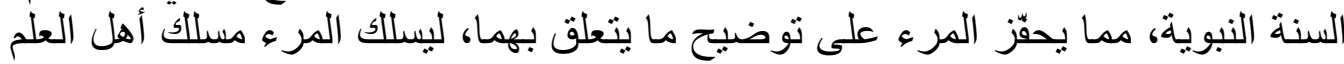
في خدمة السنة النبوية.

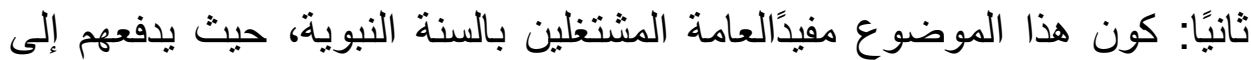

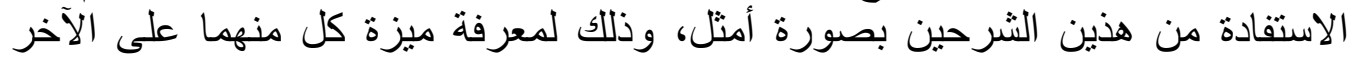
و الفروقات بينهما. ثالثً: إبراز جهود الحافظ ابن عبد البر التي بذلها في هذين الكتابين اللذين

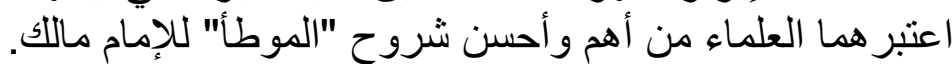

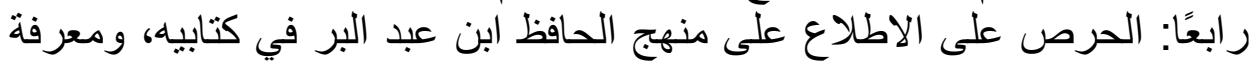

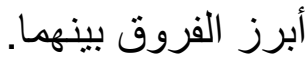

\section{خِطة البحث}

اشتمل البحث على مقدمةٍ، وأربعة فصول، وخاتمةٍ، وفهارس؛ وذلك على النحو

المقدمة: وتشتمل على بيان أهمية الموضوع، وأسباب اختياره، ومنهج العمل التالي: الفصل الأول:التعريف الموجز بمؤلف الكتابين الحافظ ابن عبد البر؛ وفيه ثمانية فيه، وخِطة البحث.

$$
\text { مباحث: : المبحث الأول: مولده. }
$$


دراسة موجزة لكتابَي"التمهيد" و "الاستذكار" للحافظ ابن عبد البر مع المقارنة بينهما

$$
\begin{aligned}
& \text { المبحث الثاني: نشأتها وطلبه للعلم. } \\
& \text { المبحث الثالث: رحلاته المبه } \\
& \text { المبحث الرابع: أثنهر شيوخه الثيه. } \\
& \text { المبحث الخامس: أشهر تلامذتهـ المبه } \\
& \text { المبحث الساد: المبحث: منزلته عند العلماءئ } \\
& \text { المبحث السابع: مصنفاته السئه } \\
& \text { المبحث الثامن: وفاته المئ. }
\end{aligned}
$$

الفصل الثاني: التعريف بكتاب "التهن: التمهيد"؛ وفيه ستة مباحث:

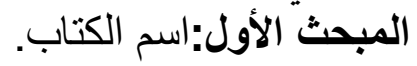

المبحث الثاني: توثيق نسبته إلى المئل المؤلف.

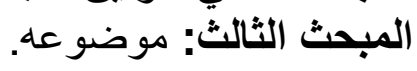

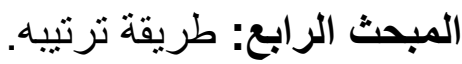

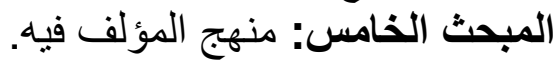

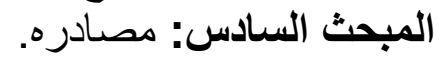

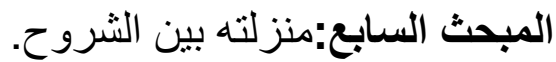

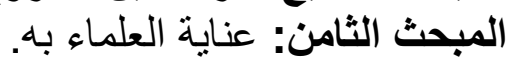

الفصل الثالث: التعريف بكتاب "الاستذكار "؛ وفيه ثمانية مباحث:

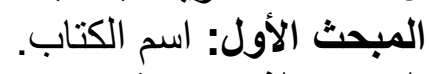

المبحث الثاني: توثيق نسبته إلى المؤلف الفئ.

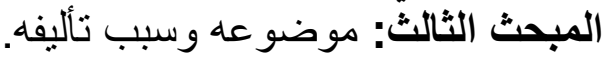

المبحث الرابع: طريقة ترنيبه.

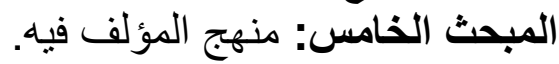

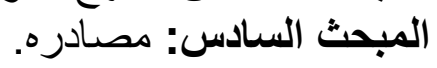

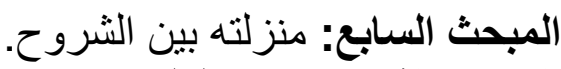

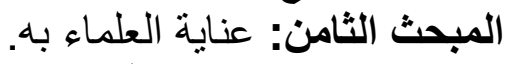

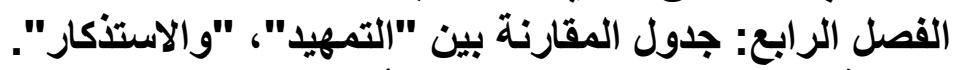

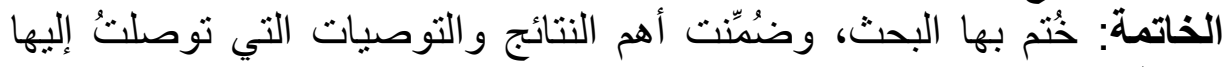

$$
\text { بفضل الله تعالى. }
$$

الفهارس: ذيّلت عملي هذا بفهرسين فنيين، وهما:

$$
\text { r - فهرس فهرس الموضور البحث. }
$$


رنهج العمل في البحث:

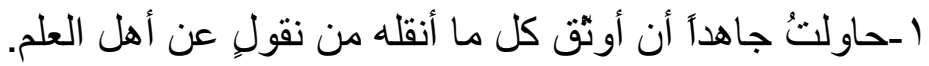

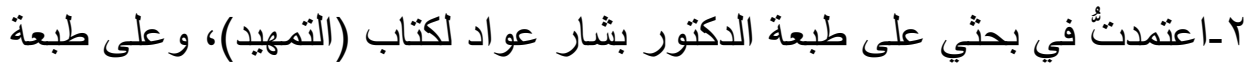
الدكتور عبذ المعطي قلعجي لكتاب (الاستذكار).

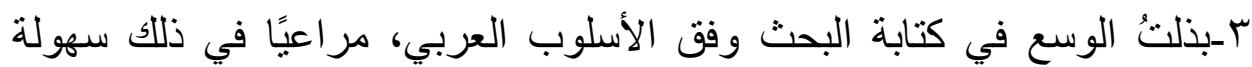

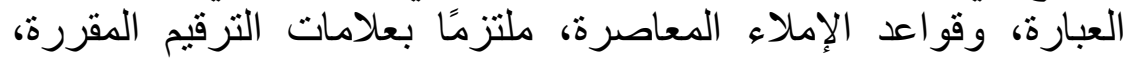

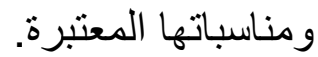

ع-جعلت صلب البحث للمادة العلمية المرتبطة بموضو عه ارتباطا وثيقًا، وجعلت

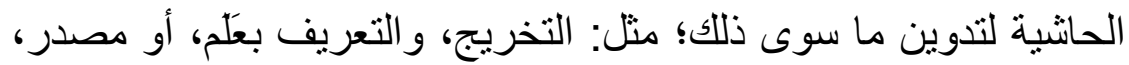
أو موقع، أو واقعة لتوبن.

0ـعُنيت بضبط ما يحتاج إلى ضبط من الألفاظ. 7-رجعت في مادة كل حاثية إلى مصنادر ها المتخصصة؛ القديمة و المعاصرة. V_ذكرت في آخر البحث ما توصلت إليه من النتائج مع ذكر التوصيات. هذا وأسأل الله جل وعلا أن يوفقي والمسلين لما يحب ويرضى، وصليى الله وسلم وبارك على نبينا محمد و على آله وصلي وصحبه أجمعين. 
دراسة موجزة لكتابَي"التمهيد" و "الاستذكار" للحافظ ابن عبد البر مع المقارنة بينهما

\section{الفصل الأول}

\section{التمريف الامجز بمؤلف الكتابين المانظ ابن عبد البر}

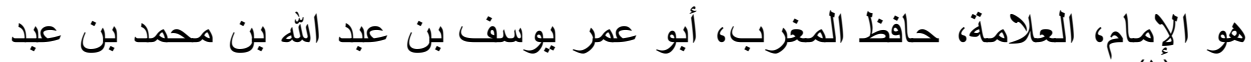

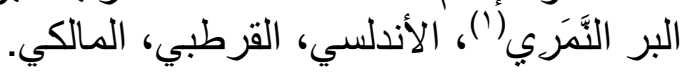

\section{المبحث الآول: مولده:}

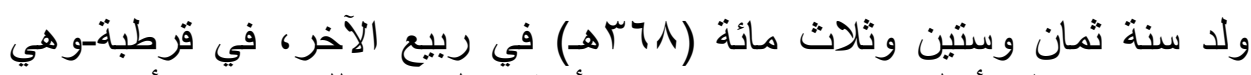

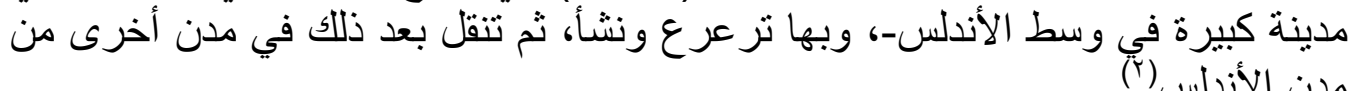

\section{المبـث الثانـي: نسشأنه وطلبه اللعلم:}

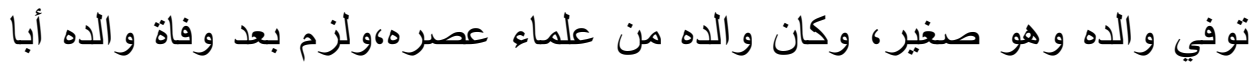

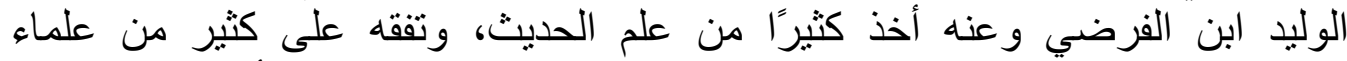

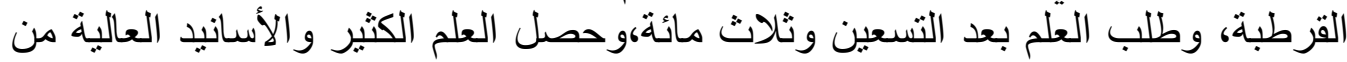

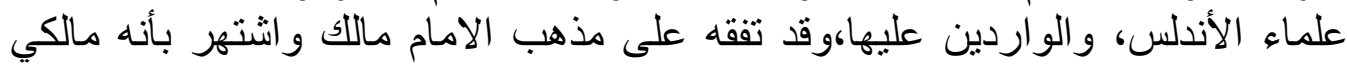
المذهب، وصنف فيه كتابه (الكافي).

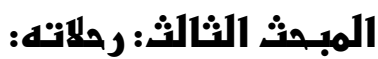

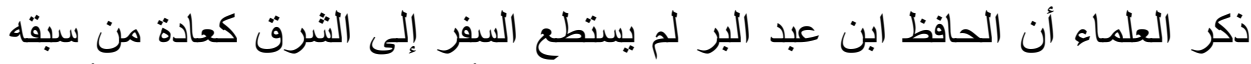

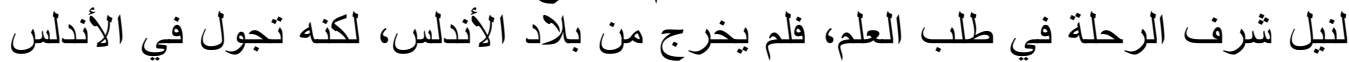

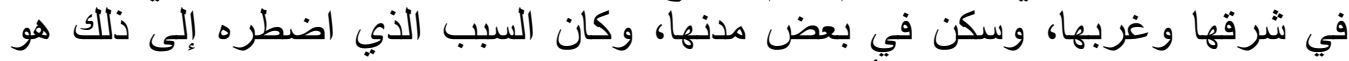

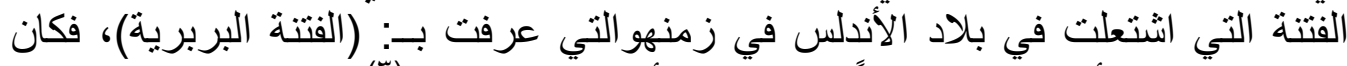

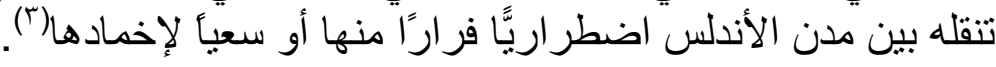

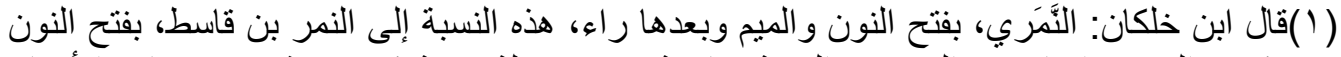
وكسر الميم، و إنما تقتح الميم في النسبة خاصنة، وهي قبيلةعربية كبيرة مشهورة.وفية النيات الأعيان

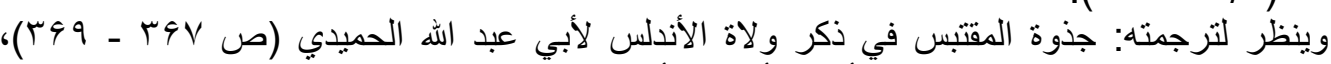

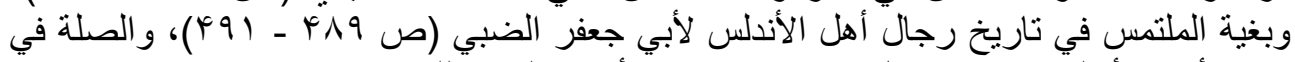

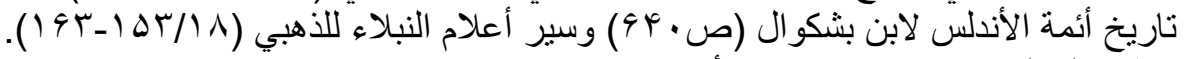

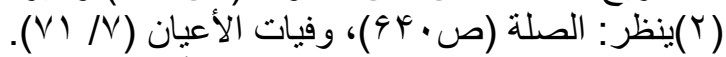

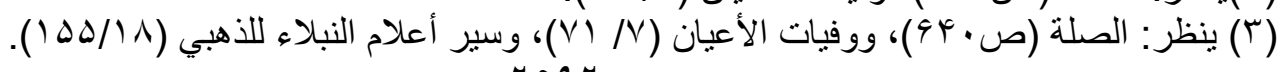


مجلة كلية الثريعة والقانون بتفهنا الأشر اف ـ دقهلية

العدد الثالث والعشرون لسنة إب ـ r الإصدار الثاني " الجزء الثالث "

\section{المبـف الرابـر: أشهر شيوخه(1):}

ا ـخلف بن القاسم بن سهل، أبو القاسم المعروف بابن الدبّّاغ.

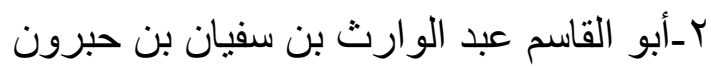

بـأبو محمد عبد اللَّه بن محمد بن عبد المؤمن.

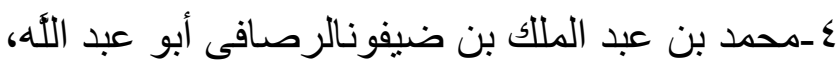

هـأحمد بن قاسم بن عبد الرحمن التميمي البزاز.

المبحث الفامسر: أشهر تلامذته(1):

1 ـأبو محمد علي بن أحمد بن سعيد بن حزم القرطبي الظاهري.

r ـأبو عليّ حسين بن محمد بن أحمد الجيانيالغسّاني.

r ـأبو عبد اللهمحمد بن فتوح الحميديالأنصاري.

ع ـأبو بحر الأسدي، سفيان بن العاص الأندلسى.

هـموسى بن عبد الرحمن بن خلفالثاطبي.

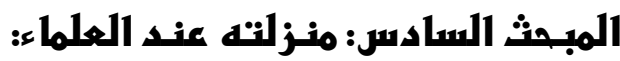

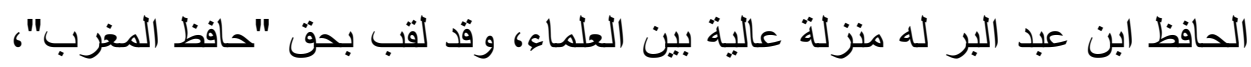

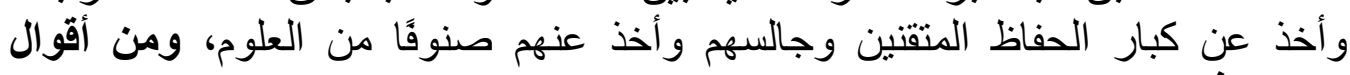

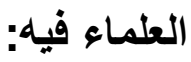
قال أبو الوليا الباجي:(لم يكن بالأندلس مثل أبي عمر في الحديث، وهو أحفظ أهل (المغرب) (بال) وقال الحميدي:(فقيه حافظ مكثر، عالم بالقراءات وبالخلاف، وبعلوم الحديث

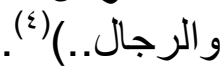
وقال أبو القاسم ابن بشكوال:(ابن عبد البر إمام عصره، وواحد دهره)(ْ).

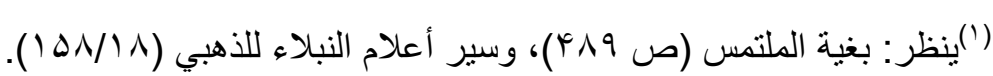

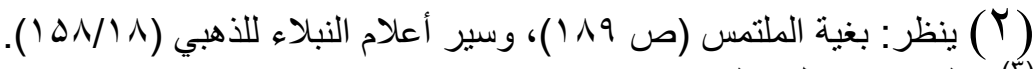

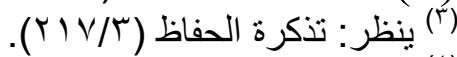

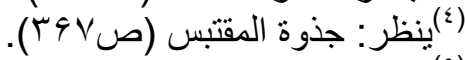

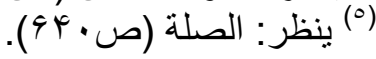




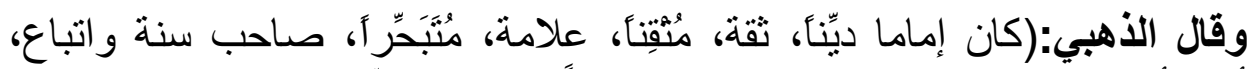

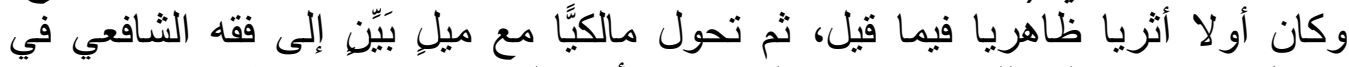

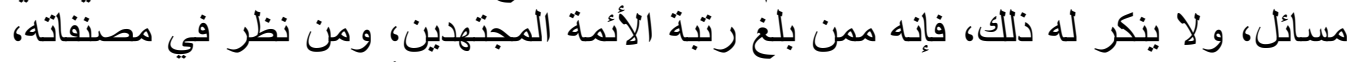

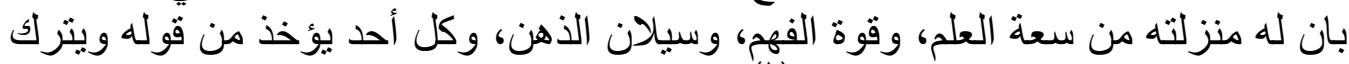

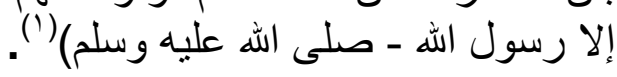

\section{المبــث السابـر: مصنهفاته:}

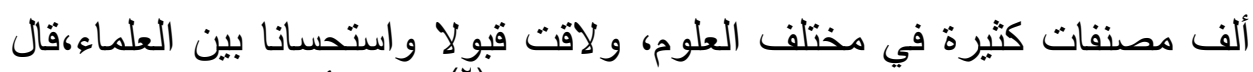

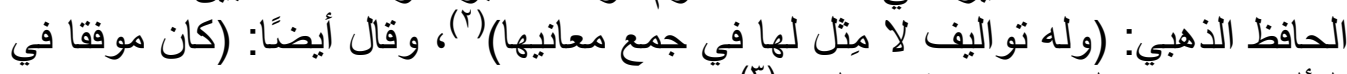

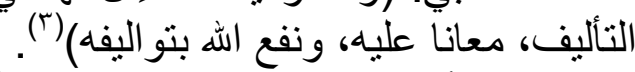

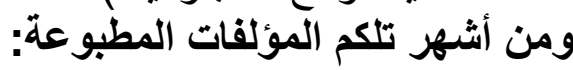

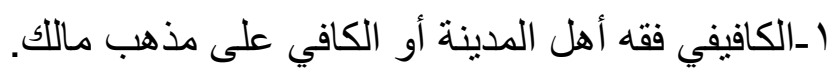
r _الاستيعاب في معرفة الأصحاب. r-جامع بيان العلم وفضله. ع ـالإنباه عن قبائل الرواة. هـالدرر في اختصـار المغازي و السير. 7_الاستغناء في معرفة المشهورين من حملة العلم بالكنى. V_اختلاف أقو ال ماللك و أصحابه. Aـ الأجوبة عن المسائل المستغربة من كتاب البخاري.

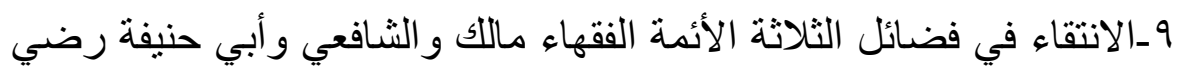
الله عنهم. • (1 - ـ أدب المجالسة وحمد اللسان.

\section{المبحث الثامن:وفاته:}

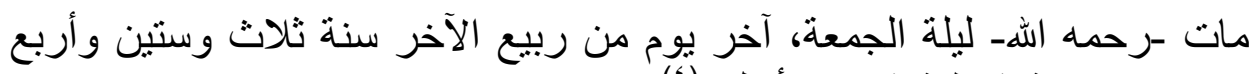

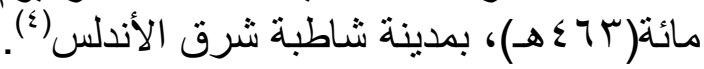

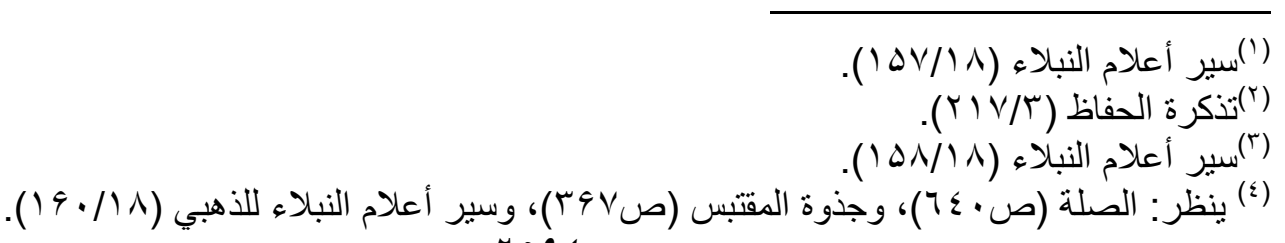




\section{النمل الثثاني}

\section{التمربف بكتاب " التمهميد "}

\section{المبحث الأول: اسم الكتناب:}

"التمهيد لما في الموطأ من المعاني والأسانيد في حديث رسول الله صلى الله عليه وسلم"(')

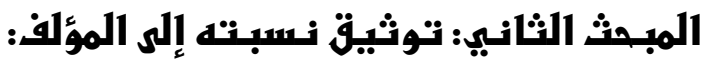

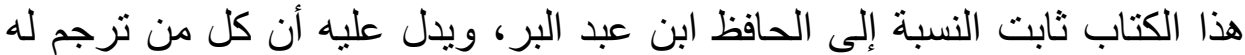

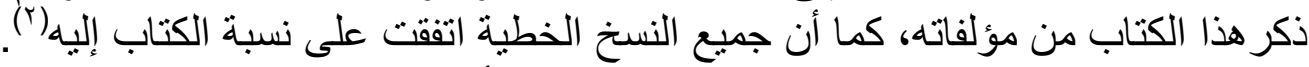

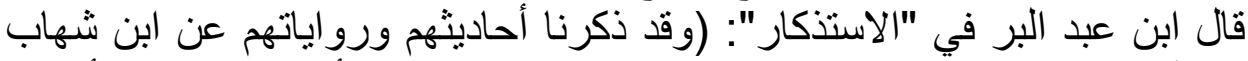

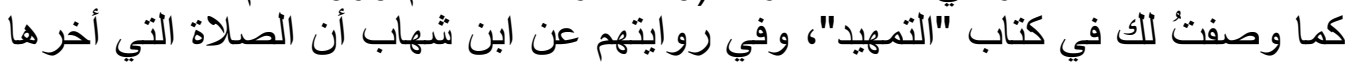

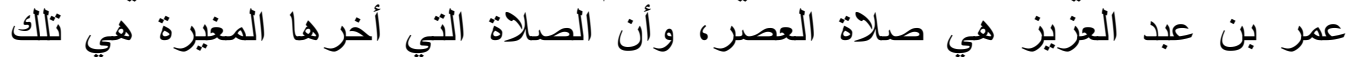
(أيضنًا) (r) وقال ابن حجر: (كتاب "التمهيد" و "الاستذكار" كلاهما في شرح "الموطأ" لأبي عمر يوسف ابن عبد البر)( (؟). المبــث الثنالث: موضو عهد:

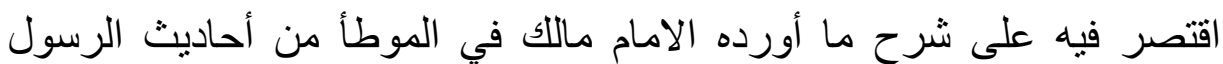

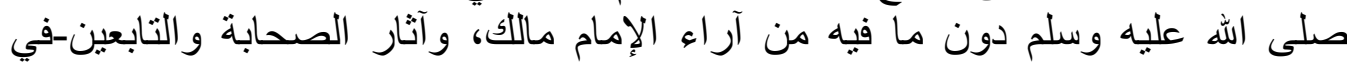

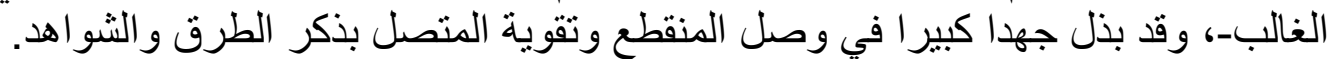

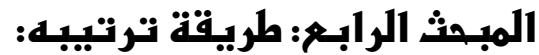

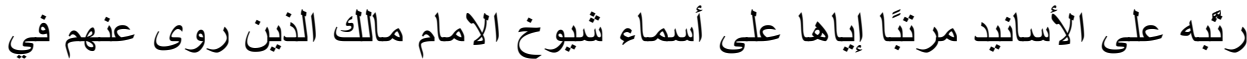

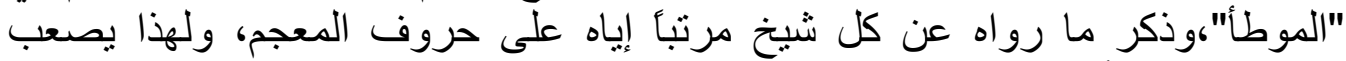

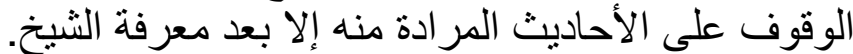

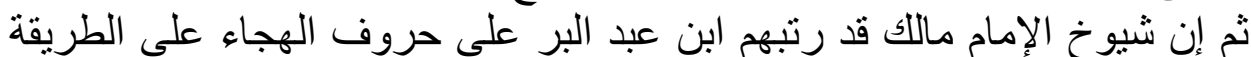

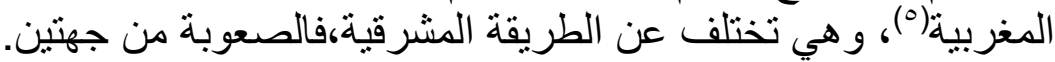

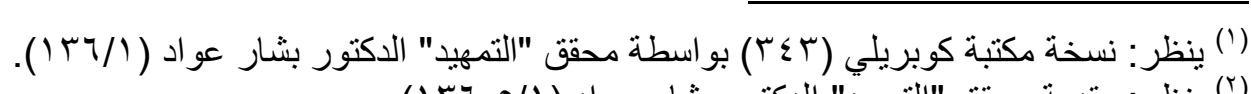

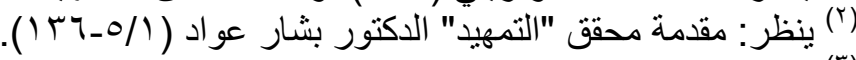

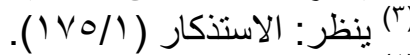

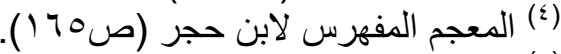

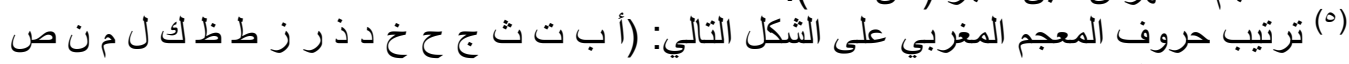


فإذا أراد الباحث الإطلاع على مسألة من الكتاب فعليه أن يكون ملِّمَ بأحاديث

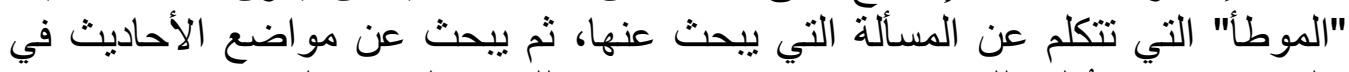

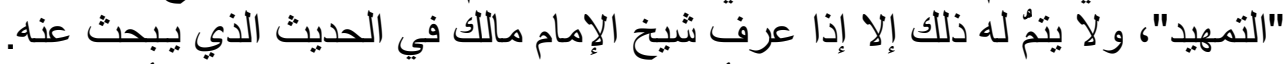

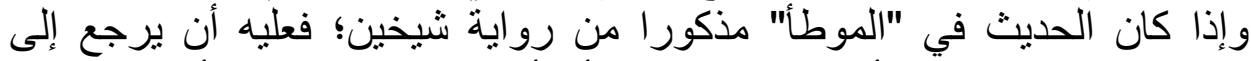

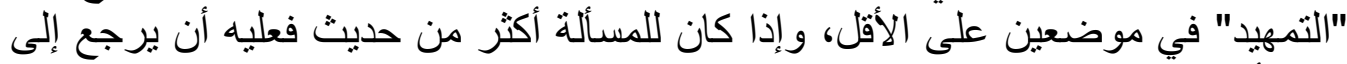

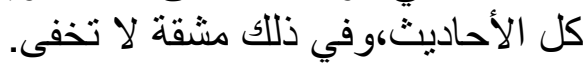

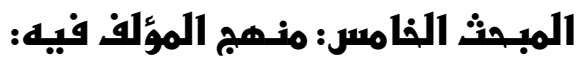

قد ذكر ابن عبد البر منهجه في مقدمة كتابه، ويمكن اختصاره في هذه النقاط التالية:

1-/ قدم للكتاب مقدمة حديثية نفيسة حيث تكلم على الحديث المتصل والمبل والمرسل

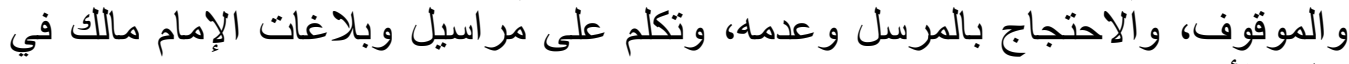
"الموطأ". r-/ تكلم على اتفاق رواة "الموطأ" واختلافاتهم في ألفاظ الأحاديث و أسانيدها، فهو

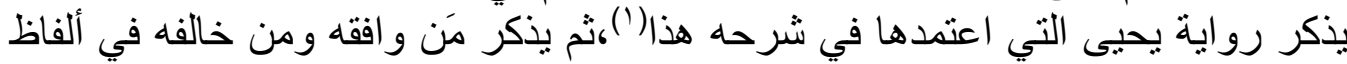

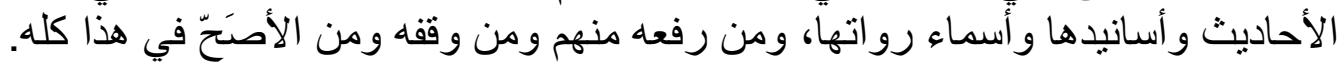

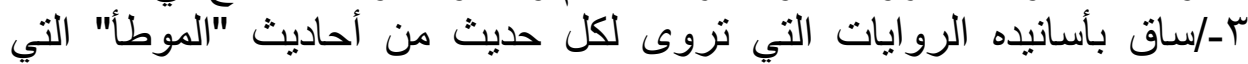

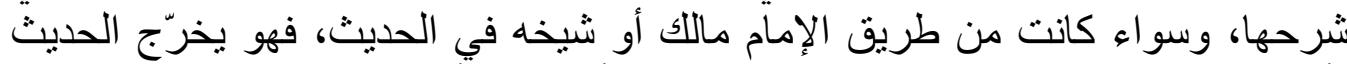

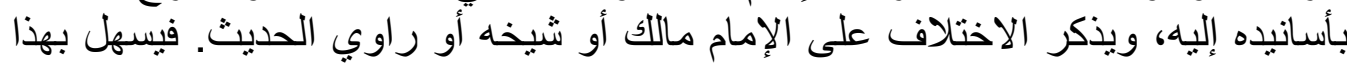

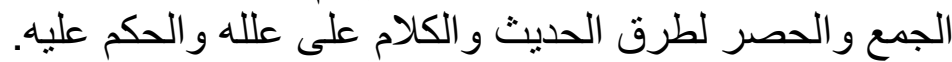
ـ-/ شرح الكلمات الغريبة والمشكلة شرحأ و افيًا، وذكر أقاويل أهل اللغة المعتمد

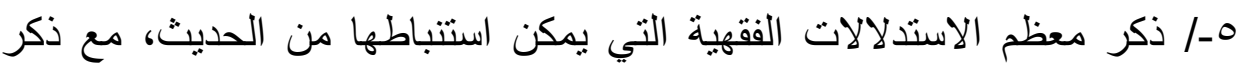

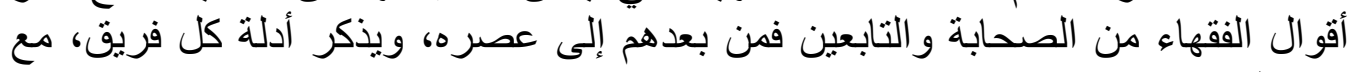

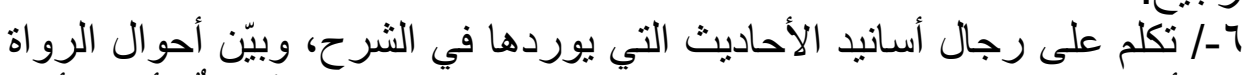

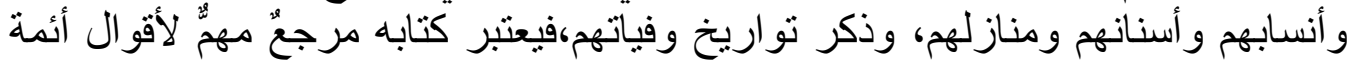

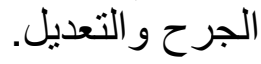

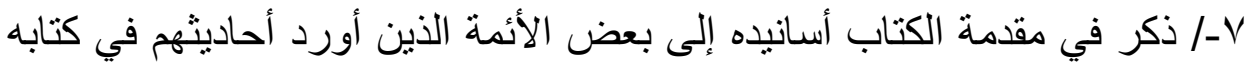

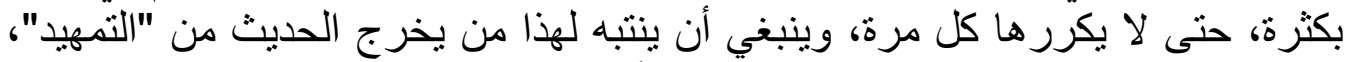

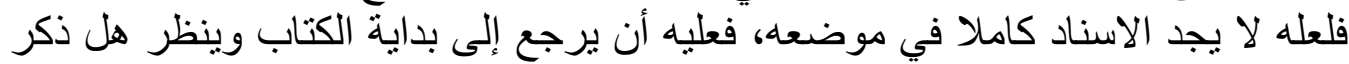

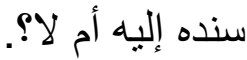

(') اعتمد على رواية يحيى الليثي لثهرته، و لاعتماد علماء أهل بلده عليها. أشنار إلى ذلك ابن عبد البر 


\section{المبـهث السادسر: مصادره:}

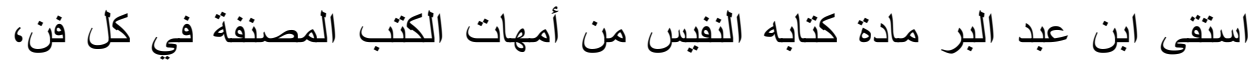
فاعتمد في الحديث على كتب الجوامع و المسانيد والسنن، وفي الآثار على المكن المصنفات،

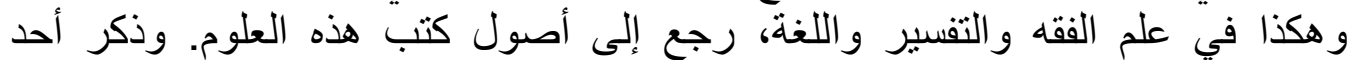

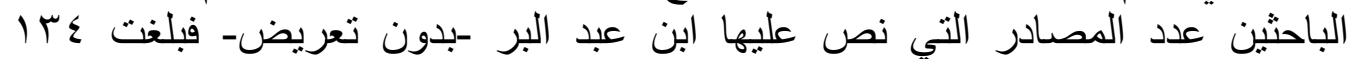

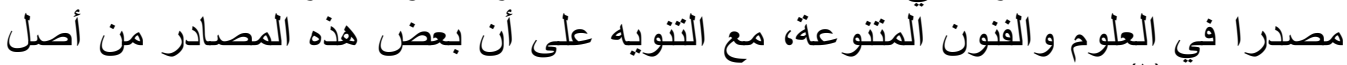

أندلسي نادر (') - (1)

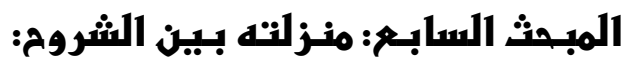

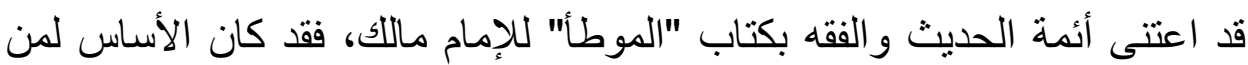

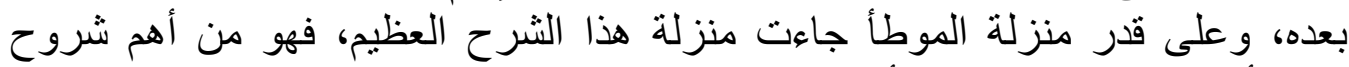

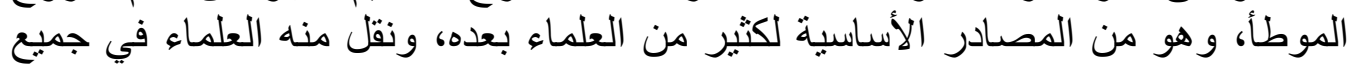

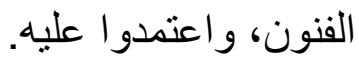
قال ابن حزم: ("التمهيد" لصاحبنا أبي عمر لا أعلم في الكلام على فقه الحديث

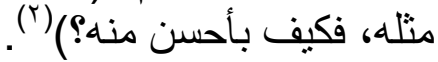

وقال أبو علي الغساني: (وكتابه "التمهيد" لم يتقدمه أحدٌ إلى مثلك)(ب).

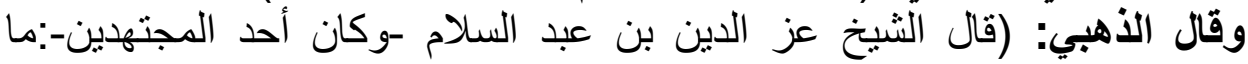

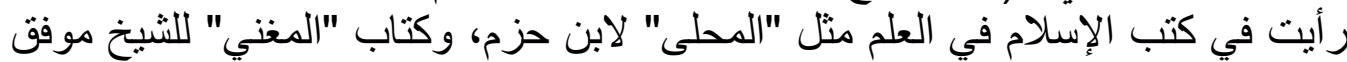

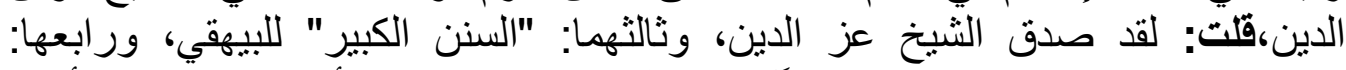

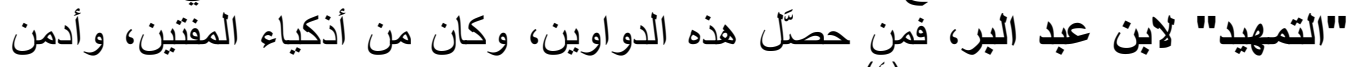

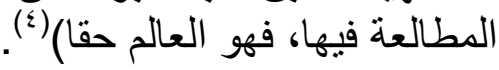

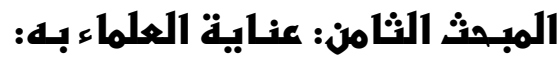

كثرت الأعمال العلمية حول هذا الكتاب، و هذا بذل على عنداية العلماء العاء به، فمنها:

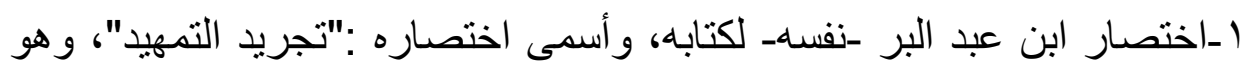
مطبوع.

ץ_اختصار "التمهيد"لمحمد بن عبد الله اللبلي(0 إ0هـ)، وهي في حكم المفقود. ب-تجريد مسائل التمهيدللشيخ سليمان بن حمدان، وهو موجود في في السجلات القديمة في فهرس مخطوطات جامعة الإمام محمد بن سعود الإسلامية

(') ينظر للمزيد مقدمة رسالة "المنهج النقدي عند الحافظ ابن عبد البر من خلال التمهيد" للاكتور طه

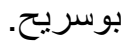

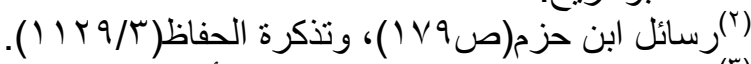

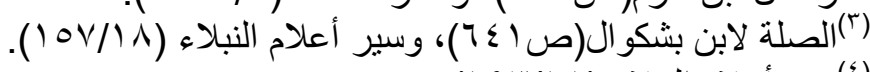


دراسة موجزة لكتابَي"التمهيد" و "الاستذكار" للحافظ ابن عبد البر مع المقارنة بينهما

بالمملكة العربية السعودية.

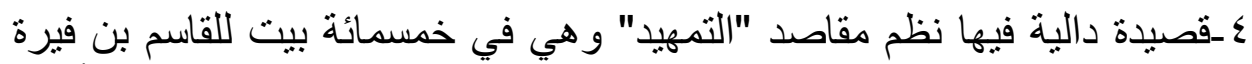

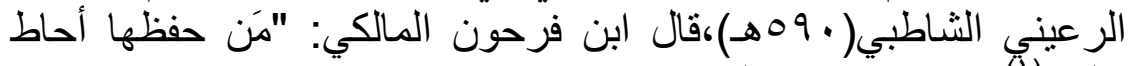
علما"(')، و هي في حكم المفقود.

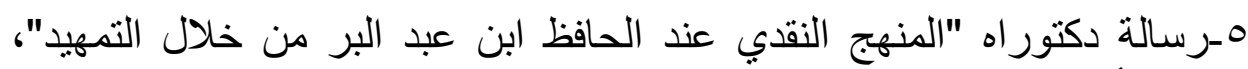
أعدّها: طه بن علي بوسريح، بالجي الفدامعة الزيتونية بتونس.

\section{ومن طبعاته - على ترتيبه الأصلى-:}

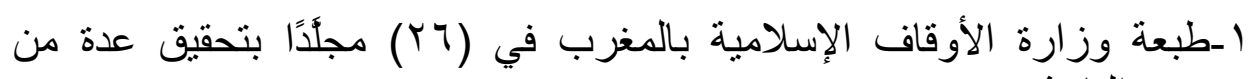
الباحثين.

r-طبع بمؤسسة الفرقان للتراث الإسلامي، في (IV) مجلًَّا بتحقيق الدكتور بشار

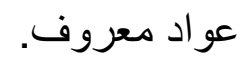

r-طبع ضمن مجموعة "شروح الموطأ" في (Y0) مجلدآ، الأخيران منه للفهارس، بتحقيق الدكتور عبد الله بن عبد المحسن التركي،بمركز هجر للبحوث

$$
\text { و الدر اسات. }
$$

\section{وطبع الكتـاب طبعـات أخرى روعي فيهـا الترتيب الفقهى أو على أبواب "الموطأ"فمنها:}

ا-فتح البر" في الترتيب الفقهي لتمهيد ابن عبد البرّ" " للاكتور عبد الرحمن

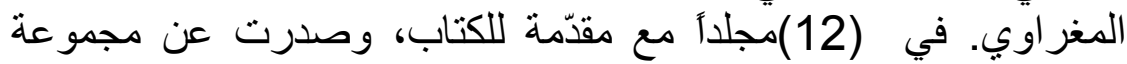

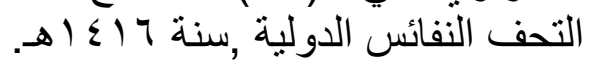

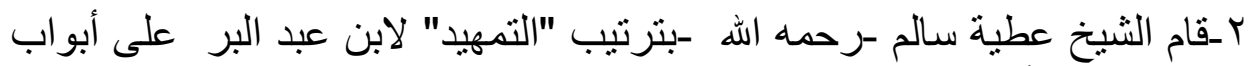

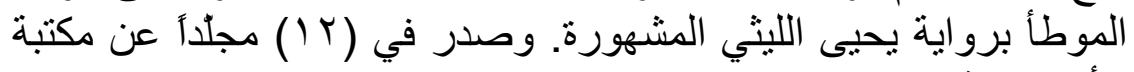

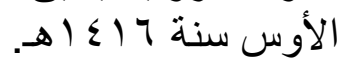

ץ-طبع كذلك مرتبأ على الأبواب الفقهية في دار الفاروق الحديثة بتحقيقأسامة بن إبر اهيم في (1) (1) مجلّاً، منها مجلّأن للفهارس. 


\section{الفمل الثالث \\ التعريف بكتاب " الاستذكار "}

\section{المبــن الأول : اسلم الكتناب:}

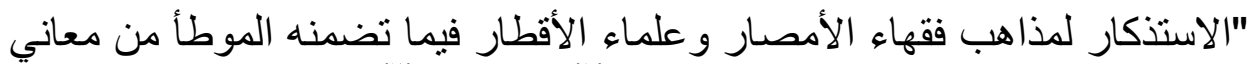

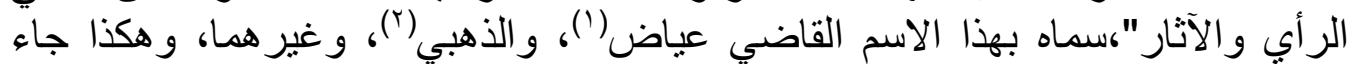

في نسخ الكتاب الخطية"(")

والأشهر بين العلماء استعمال الاسم المختصر له، وهو "الاستذكار".

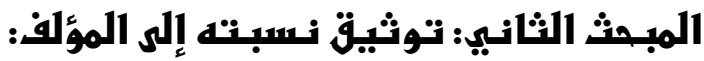

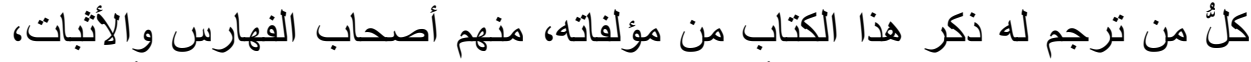

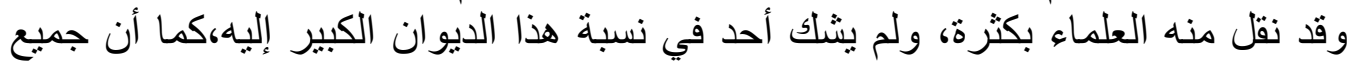
النسخ الخطية للكتاب اتفقت على نسبة ولثة الكتاب إليه.

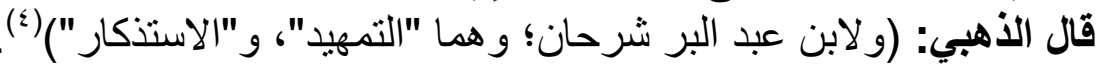

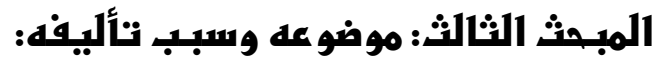

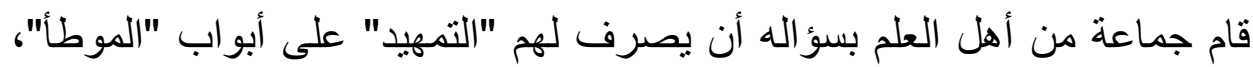
مع حذف الشواهد والطرق، وذكر اختلاف العلماء، فألف لهم هذا الكتابمر اعيًا الإيجاز

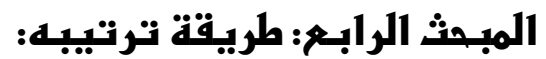

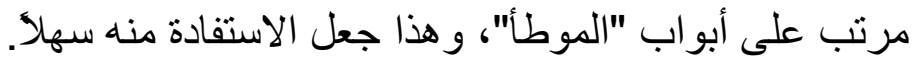

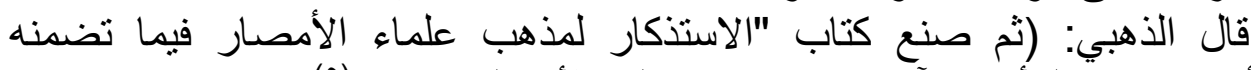

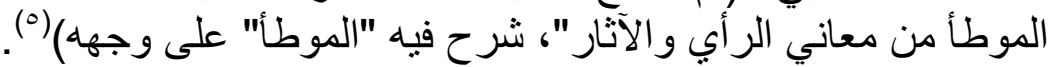

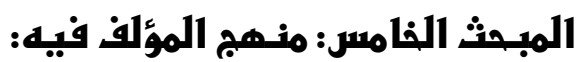

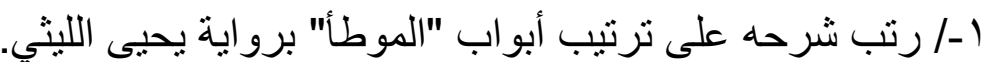

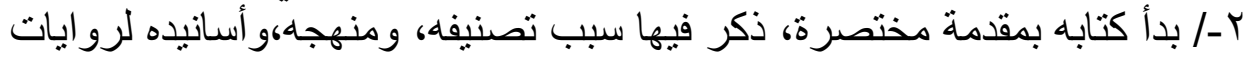

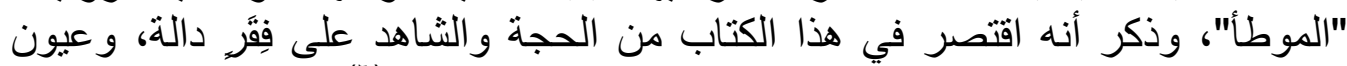

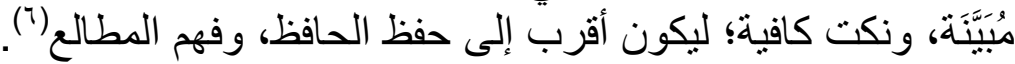

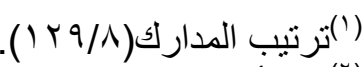

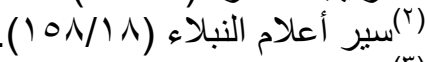

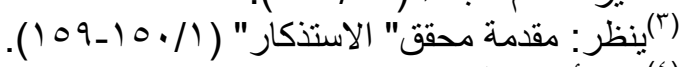

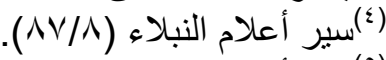

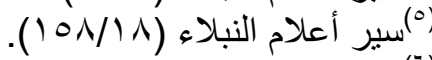

$$
\begin{aligned}
& \text { (7) ينظر : الاستذكار (10/1) (1) (1). }
\end{aligned}
$$


دراسة موجزة لكتابَي"التمهيد" و "الاستذكار" للحافظ ابن عبد البر مع المقارنة بينهما

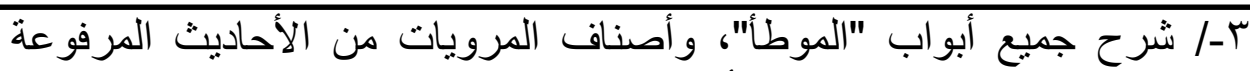

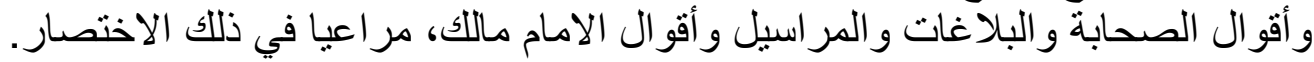

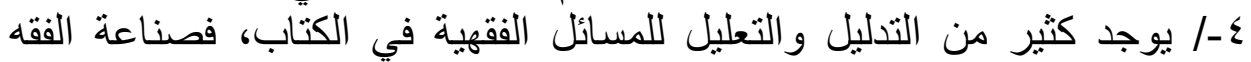

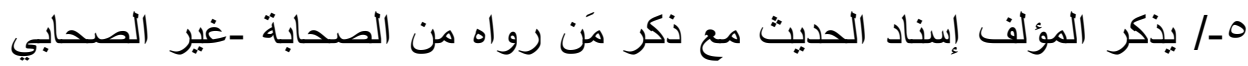
غالبة على الكتاب. - ماب.

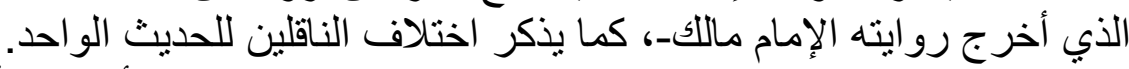

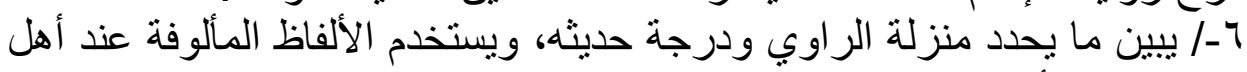

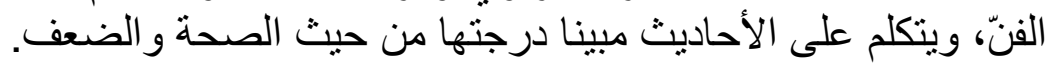

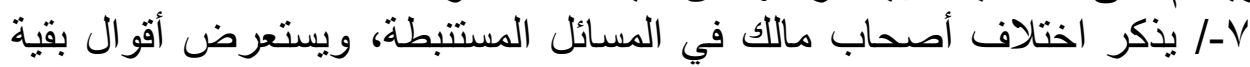

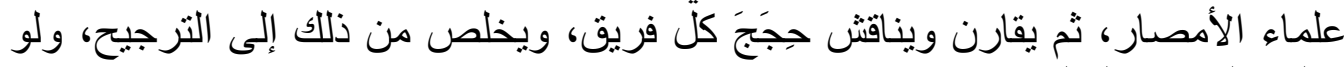

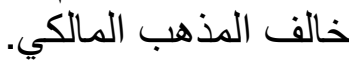
1-/ يحيل إلى "التمهيد" في بعض المسائل، لكونه أسهب الكلام فيها هناك.

\section{المبـثن السادسر: مصادره:}

يعد المصدر الأساسي له كتاب"التمهيد"، على أنه استفاد من مصادر أخرى كعادته في كتبه.

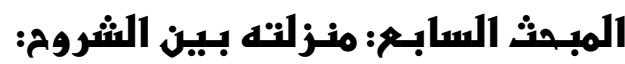

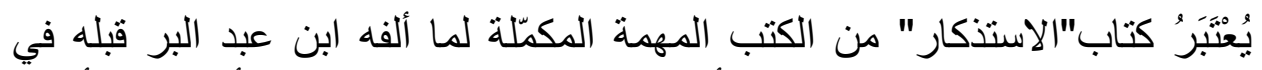

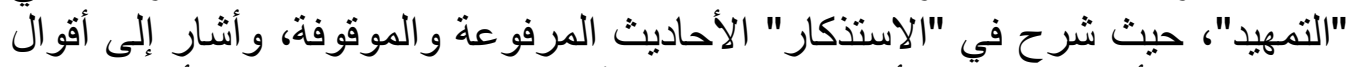

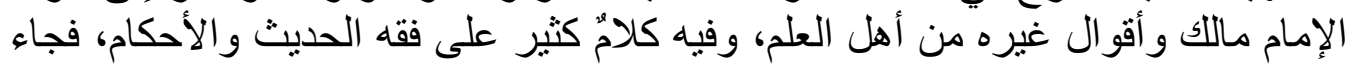

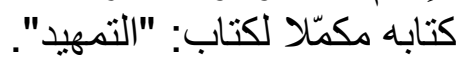
أنثد أبو طاهر الستّلفي فيه:

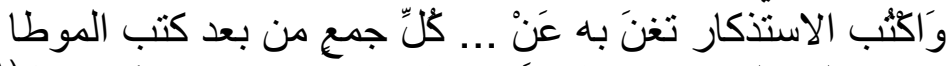

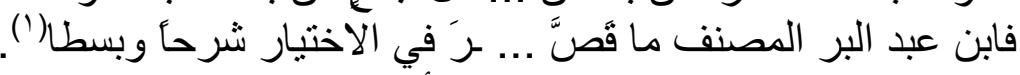

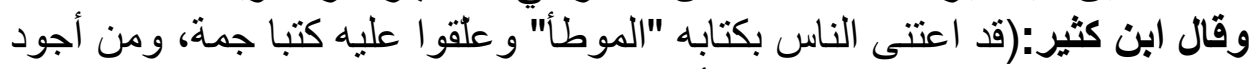

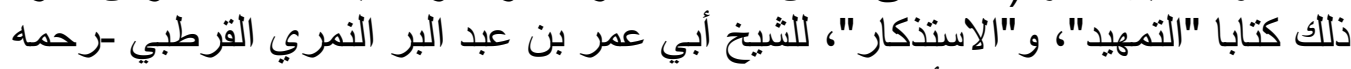

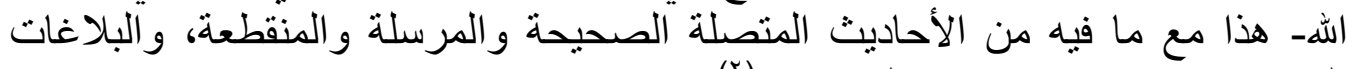

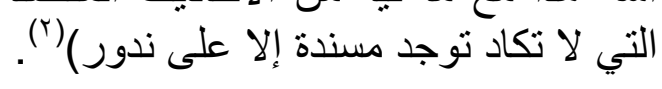

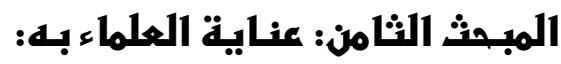

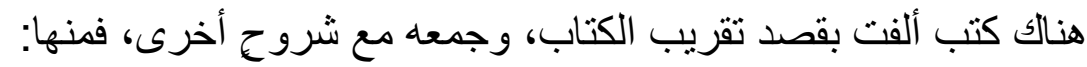

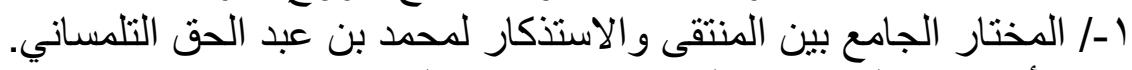

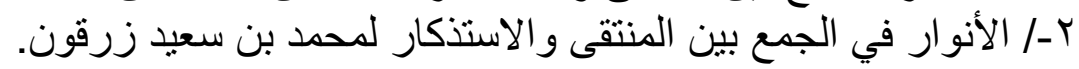

(1) (مقدمة إملاء الاستذكار للحافظ أبي عمر ابن عبد البر القرطبي لأبي طاهر السبّلفي. (ص (ه).

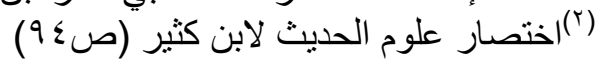


مجلة كلية الشريعة والقانون بتفهنا الأشراف ـ دقهلية

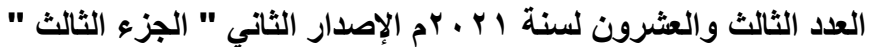

"-/الأنوار في الجمع بين المنتقى والاستذكار، تأليف أبي الحسن علي الملفي.

و ومن طبعاتهة:

للفهارس، و هذه الطبعة كثيرة الأخطاء مع حواش طويلة، و أكثر ها مأخوذة من "التمهيد".

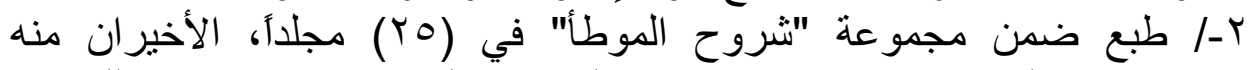

للفهارس، بتحقيق الدكتور عبد الله بن عبد المحسن التركي،بمركز هجر هو للبحوث

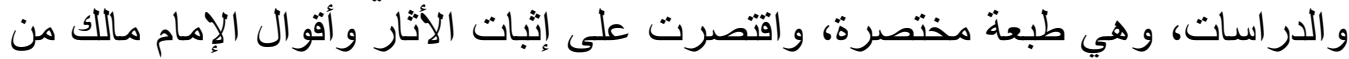
"الاستذكار"، أما بقية الكتاب الذي فيه الأحاديث المرفوعة فئه فاكتفو الباير ادها من "التمهيد"، مع أن هنالك فو ائد كثيرة من الأحاديث التي حذفو ها من "الاستذكار" ليست في "التمهيد".

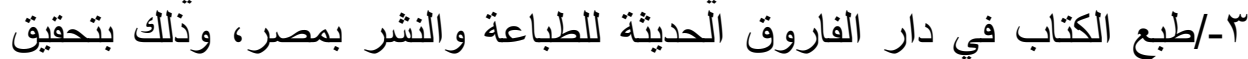

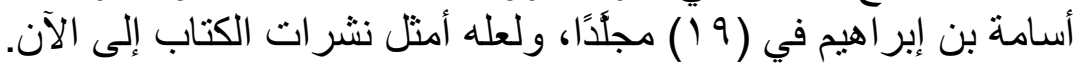

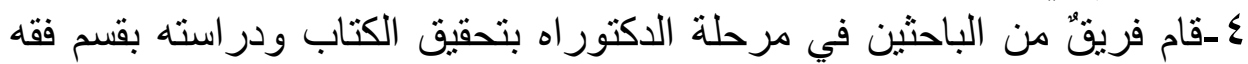

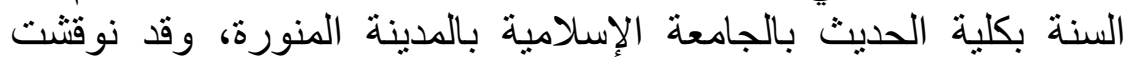

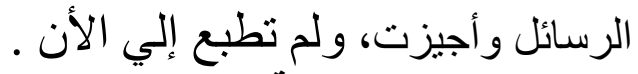

الفصل الرابع: جدول المقارنة بين كتابي "التمهيد" و "الاستذكار" ل"(').

\begin{tabular}{|c|c|c|c|}
\hline الاستذكار & التمهيد & العنصر & الرقم \\
\hline 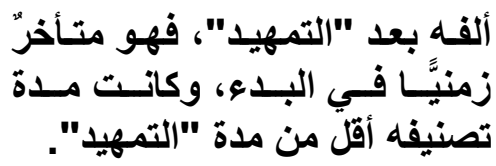 & 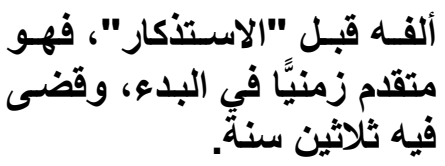 & تأريخ التأليف ومدته & .1 \\
\hline 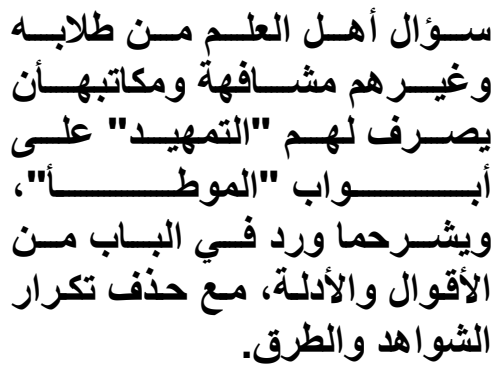 & 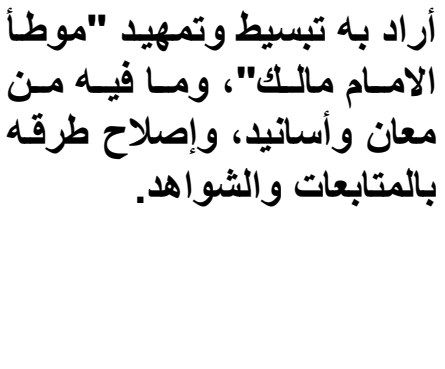 & سبب تصنيفه &.$r$ \\
\hline 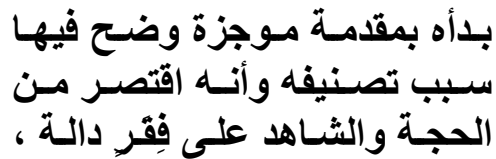 & 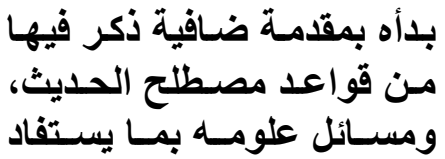 & مقدمة الكتاب &.$\mu$ \\
\hline
\end{tabular}

(') هناك رسالة علمية في "المقارنة بين التمهيد والاستذكار" بكلية الدعوة الإسلامية بليبياهولم أعثر عليها. 
دراسة موجزة لكتابَي"التمهيد" و "الاستذكار" للحافظ ابن عبد البر مع المقارنة بينهما

\begin{tabular}{|c|c|c|c|}
\hline ليكون أقرب إلى حفظ الحافظ. & 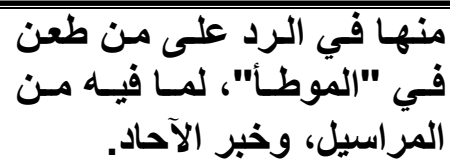 & & \\
\hline 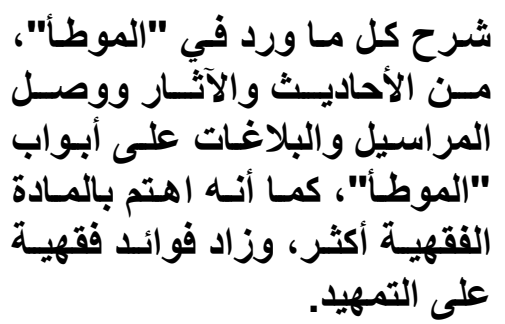 & 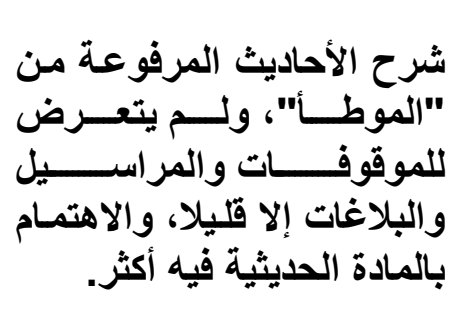 & الكتابوع & . \\
\hline 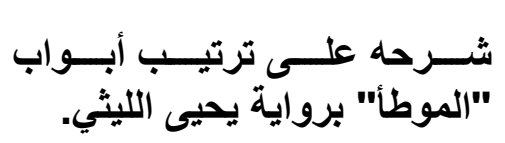 & 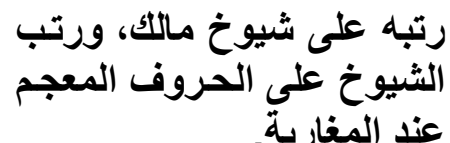 & ترتيب الكتاب & .0 \\
\hline 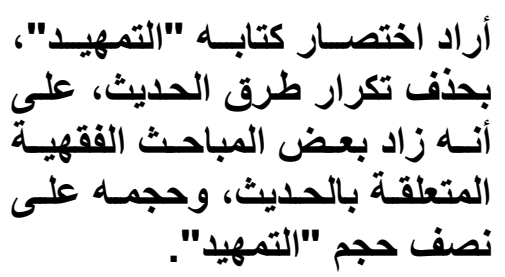 & كتابه مفصتّا، فهو الاختصار، ومع ذلك أتى & والاختصار & .9 \\
\hline 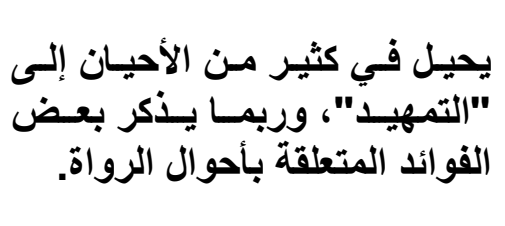 & 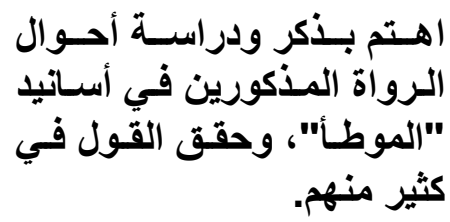 & بالرواة والحعم عليف &.$V$ \\
\hline بإيجاز إلى التمهيد أحيانا، أو يذكره & 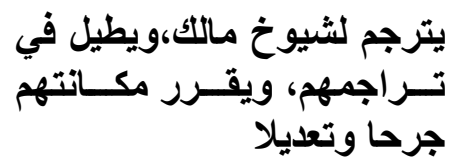 & تراجم شيوخ &.$\wedge$ \\
\hline الليثي روايـة يحيـى بـن يحيـى & رواية يحيى بن يحيى الليثي & 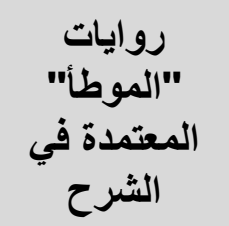 & .9 \\
\hline التمكرها بدون أسـانيد، ويحيل إلى & 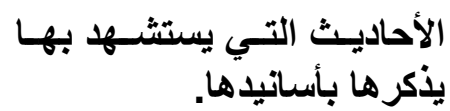 & بالأسانيا & .1 . \\
\hline
\end{tabular}


مجلة كلية الثريعة والقانون بتفهنا الأشر اف ـ دقهلية العدد الثالث والعشرون لسنة إب ـ r الإصدار الثاني " الجزء الثالث "

\begin{tabular}{|c|c|c|c|}
\hline 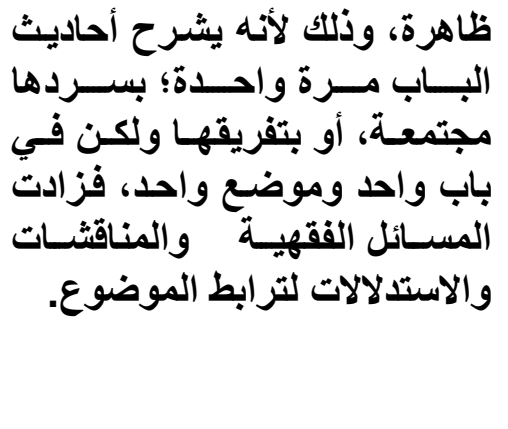 & 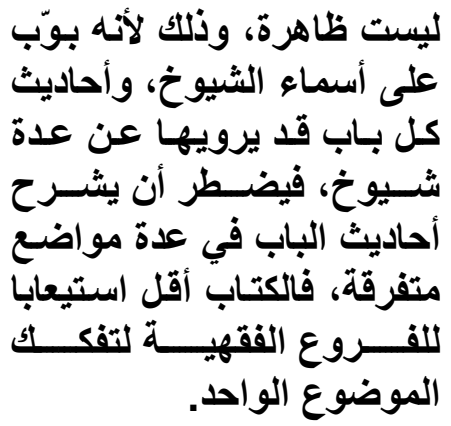 & والموضوة وحدة الفرة & .11 \\
\hline 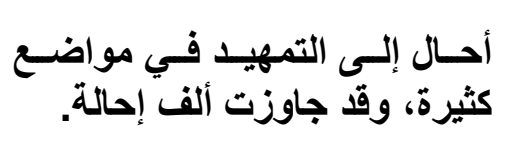 & 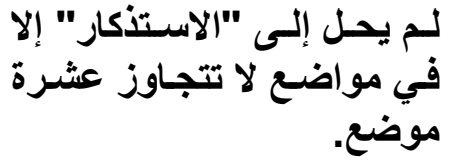 & الإحتاب الآخر على & $.1 Y$ \\
\hline \multicolumn{2}{|c|}{ 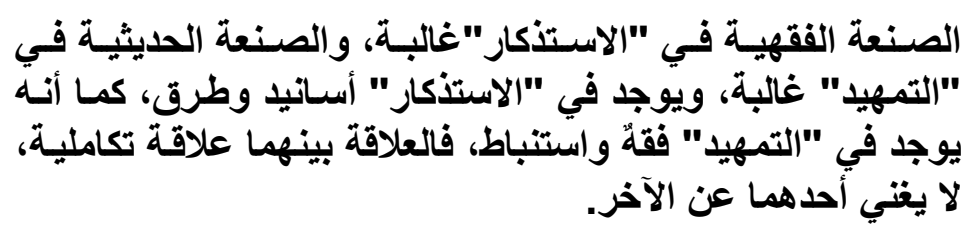 } & والمقترق & .14 \\
\hline "لم يختم إلا بشرح فتر آخر حديث من & 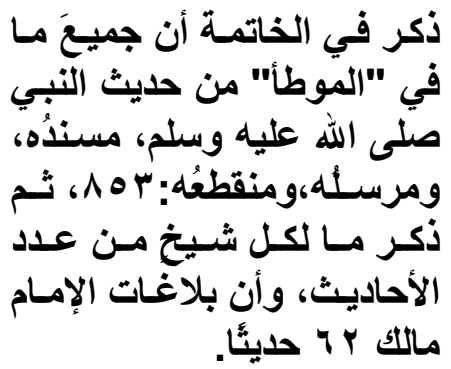 & الخاتمة & $.1 \varepsilon$ \\
\hline 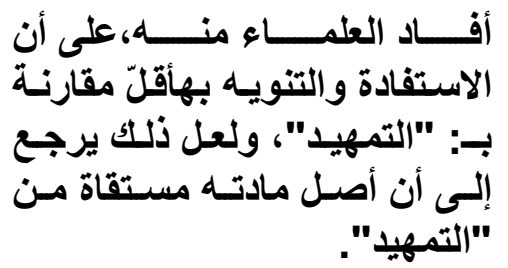 & 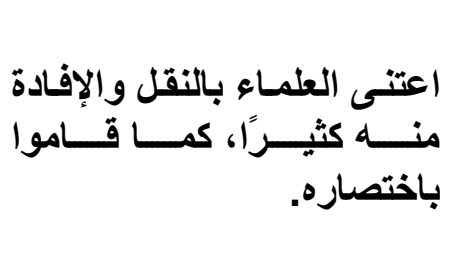 & عناية العلماء & .10 \\
\hline
\end{tabular}


دراسة موجزة لكتابَي"التمهيد" و "الاستذكار" للحافظ ابن عبد البر مع المقارنة بينهما

\section{الخاتمة في ذكر أهم نتائج البحث:}

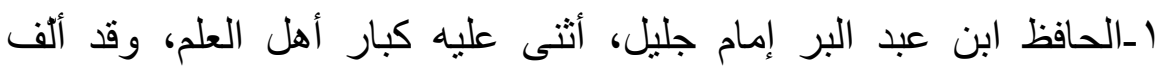

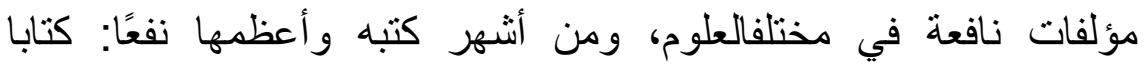
"التمهيد"، و "الاستذكار ". r _ألف كتابه "التمهيد" لشرح الأحاديث المرفوعة من "الموطأ" و أطال الكلام في طرق الأحاديث و أسانيدها. r_ألف كتابه "الاستذكار" تسهيلا للاستفادة في "الموطأ"، واختصر الكلام في طرق الأحاديث و اهتم بالصنعة الفقهية. لتهية. ع _لكتابي "التمهيد"، و "الاستذكار" ميزة يجعل القارئ لا يمكنه الاستغناء عن أحدهما.

التوصيات : الكبرى، و إبراز ما يتميز كلّ منها.

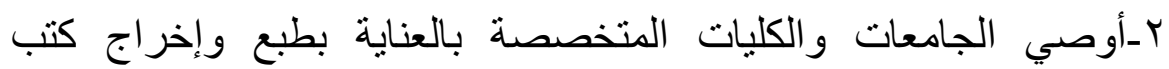

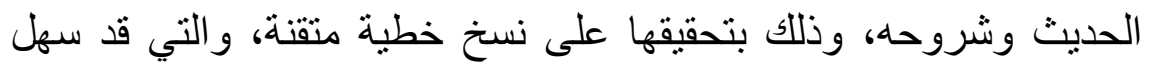
الوصول إليها في عالم انترنت اليوم.

rأوصي بتبني الجامعات و المر اكز العلمية على أهمية إخر اج طبعة علمية متقنة لكتاب "الاستذكار ". ع ـأهمية إبراز جهود علماء الحديث، وذكر مناهجهم في مُصنَّفاتهم في خدمة السئنة والعناية بها؛ من خلان الئل الأبحاث العلمية، و الرسائل الجامعية. وصلى الله وسلم وبارك على عبده وسوله نبيّنا محمّة، و على آله، وصحبه أجمعين. 


\section{فهرس مصادر البحث}

ا_الاستذكار ـالجامع لمذاهب فقهاء الأمصار وعلماء الأقطار فيما تضمنه

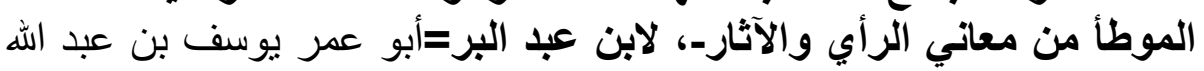

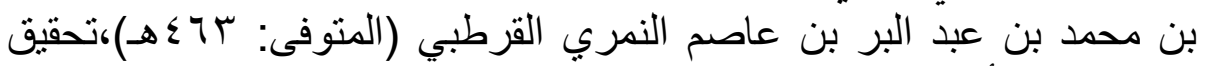
عبد المعطي أمين قلعجي، نشر دار قتيبة بدمشق مع دار الوني الوعي بحلب، الطبعة

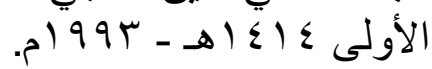

r _الباعث الحثيث شرح اختصار علوم الحديث، لابن كثير=عماد الدين أبو الفداء

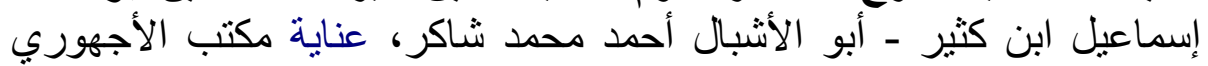

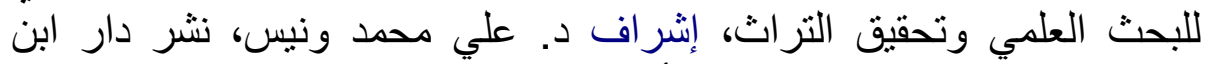

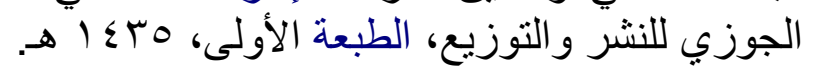

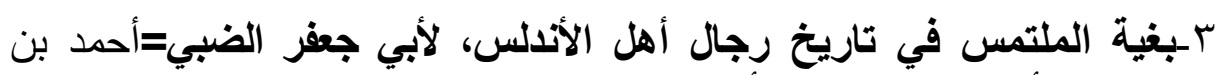

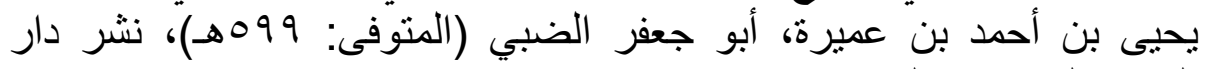

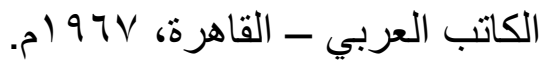

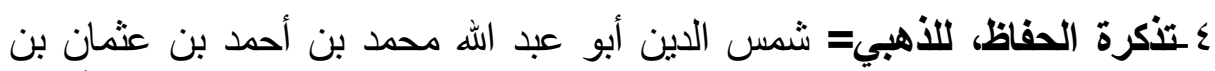

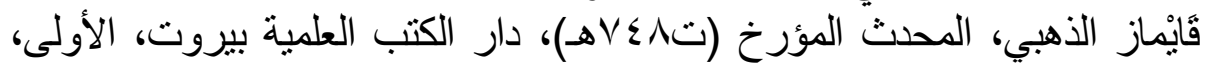
ه 9

هـترتيب المدارك وتقريب المسالك، للقاضي عياض=أبو الفضل القاضي عياض

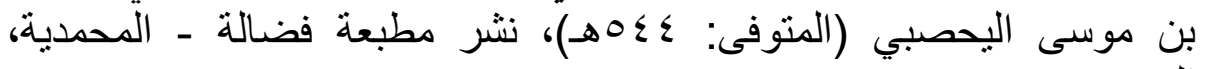
المغرب.

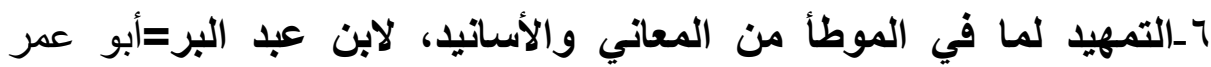

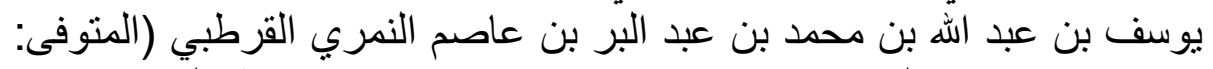

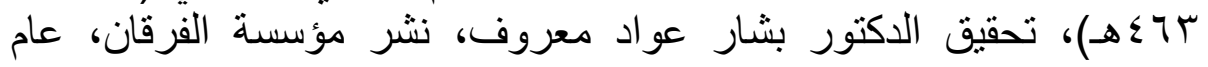
ه

V-جذوة المقتبس في ذكر ولاة الأندلس، للحميدي=محمد بن فتوح بن عبد الله

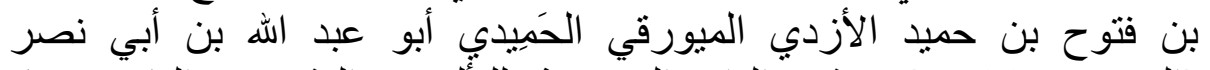

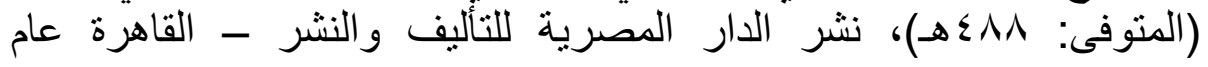
.

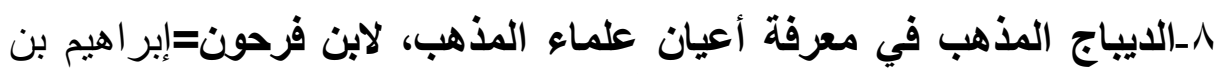

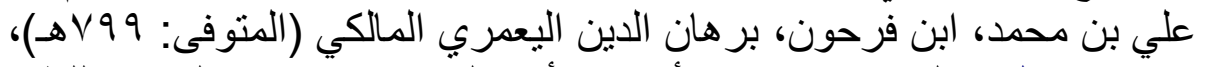

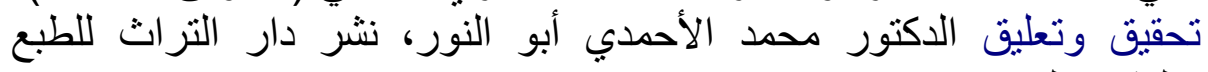

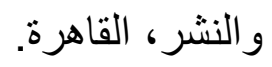




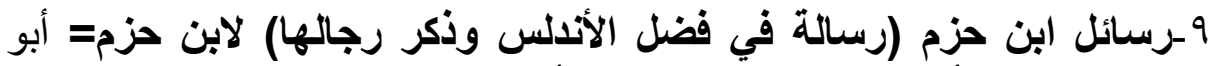

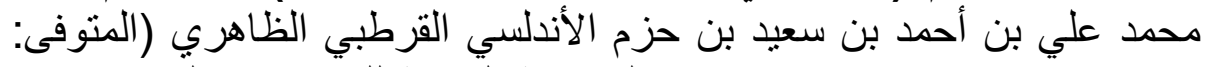

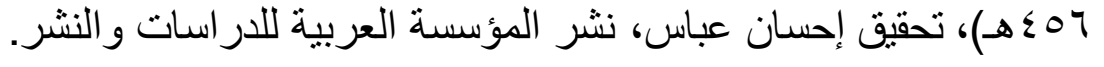

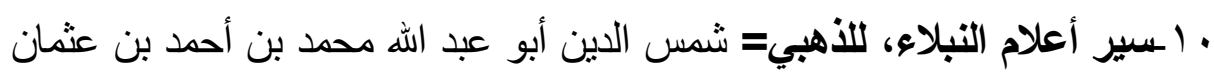

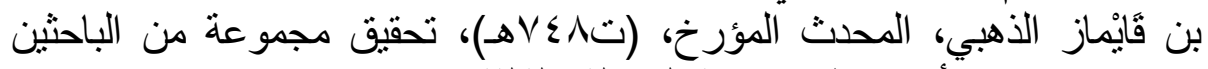

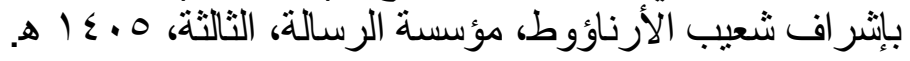

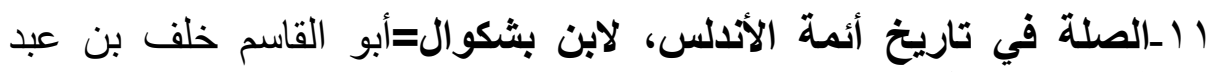

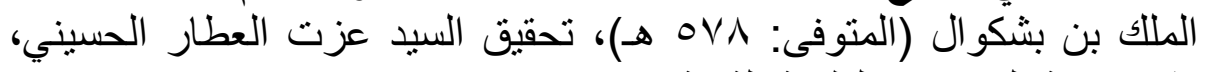

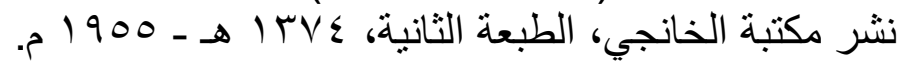

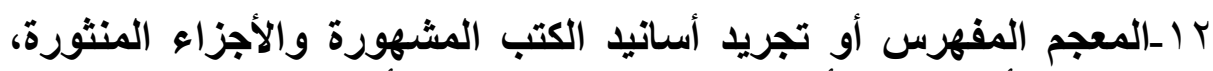

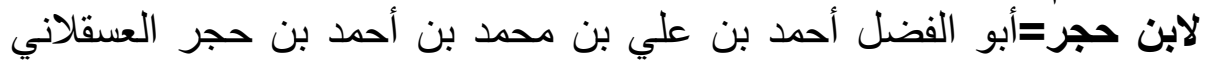

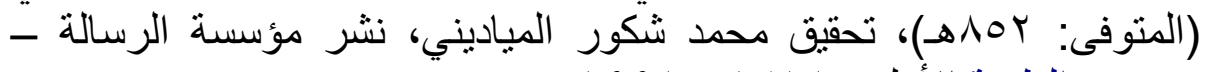

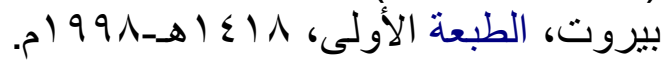

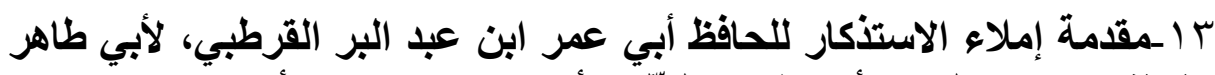

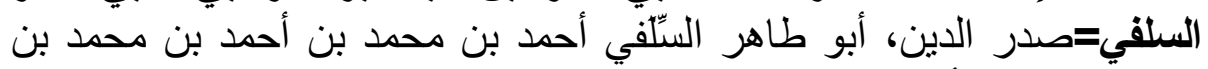

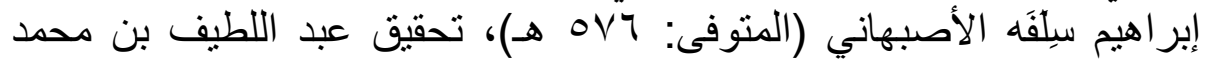

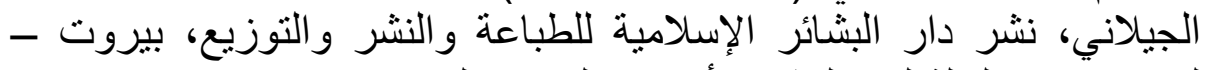

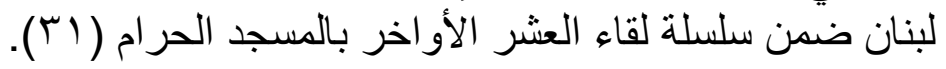

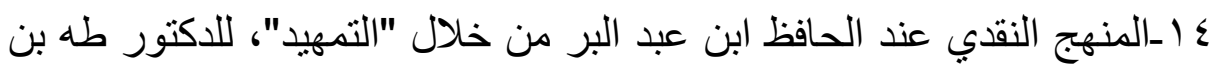

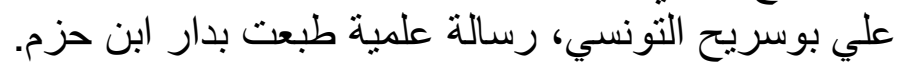

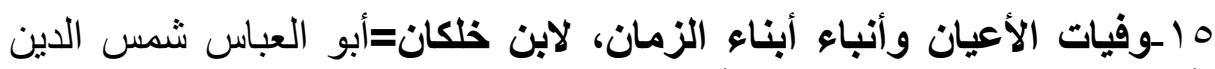

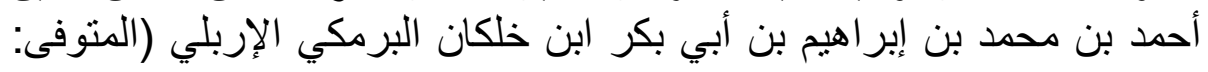
114 هـ)، تحقيق إحسان عباس، نشر دار صادر - بيروت. 